\begin{tabular}{c|c|c|}
\cline { 2 - 3 } CRITICAL & $\begin{array}{l}\text { Western Ghats } \\
\text { PARTNERSHIP FUND }\end{array}$ & Special Series \\
\cline { 2 - 3 } & &
\end{tabular}

\title{
Balitora laticauda, a new species of stone loach (Teleostei: Cypriniformes: Balitoridae) from Krishna River, northern Western Ghats, India
}

\author{
Sunil Bhoite ${ }^{1}$, Shrikant Jadhav ${ }^{2}$ \& Neelesh Dahanukar ${ }^{3,4}$ \\ ${ }^{1} 280$, Ramachagot, Satara, Maharashtra 415002, India \\ ${ }^{2}$ Zoological Survey of India, Western Regional Centre, Vidyanagar, Akurdi, Pune 411044, India. \\ ${ }^{3}$ Indian Institute of Science Education and Research, Sai Trinity Building, Sus Road, Pashan, Pune 411021, India. \\ ${ }^{4}$ Zoo Outreach Organization, 96 Kumudham Nagar, Villankurichi Road, Coimbatore 641035, India. \\ Emails: ${ }^{1}$ bhoitesunil@rediffmail.com, ${ }^{2}$ shrikantj123@yahoo.com, ${ }^{3}$ n.dahanukar@iiserpune.ac.in (corresponding author)
}

Date of publication (online): 26 September 2012 Date of publication (print): 26 September 2012 ISSN 0974-7907 (online) | 0974-7893 (print)

Editor: W. Vishwanath

\section{Manuscript details:}

Ms \# 03129

Received 22 March 2012

Final received 13 September 2012

Finally accepted 14 September 2012

Citation: Bhoite, S., S. Jadhav \& N. Dahanukar (2012). Balitora laticauda, a new species of stone loach (Teleostei: Cypriniformes: Balitoridae) from Krishna River, northern Western Ghats, India. Journal of Threatened Taxa 4(11): 3038-3049.

Copyright: () Sunil Bhoite, Shrikant Jadhav \& Neelesh Dahanukar 2012. Creative Commons Attribution 3.0 Unported License. JoTT allows unrestricted use of this article in any medium for non-profit purposes, reproduction and distribution by providing adequate credit to the authors and the source of publication.

Author Details: SUNIL BHOITE is a naturalis and interested in freshwater biodiversity and conservation. SHRIKANT JADHAV is Scientist at Zoological Survey of India, Western Regional Centre, Pune. He works on ecology, taxonomy and distribution patterns of freshwater fishes. NEELESH DAHANUKAR works in ecology and evolution with an emphasis on mathematical and statistical analysis. He also studies taxonomy, distribution and molecular phylogeny of freshwater fishes.

Author Contribution: SB collected the specimens and provided the data on habitat. SJ and ND analyzed the data and wrote the paper.

Acknowledgements: See end of this article
Abstract: A new species of stone loach Balitora laticauda is described from the Krishna River, northern Western Ghats, India. It differs from all known species of the genus in a combination of characters including: 10 transverse bands on the dorsal surface, deeper caudal peduncle, two prominent rows of papilla encircling upper lip where the proximate row has small papillae while distal row has larger papillae, 66-68 lateral line scales, 8-9 simple rays in pectoral fin, two simple rays in the pelvic fin and pectoral fin not surpassing pelvic fin base. The new species also differs from its related species in the ratios such as caudal peduncle length to depth (2.21-2.89), standard length to body depth (7.48-8.72), head length to head depth (2.11-2.50), head length to interorbital distance (2.20-2.96), head depth to head length (0.42-0.47), eye diameter to head length (0.13-0.17) and head width to gape of mouth (3.12-4.78). As percent of standard length $B$. laticauda sp. nov. differs from other related species with respect to caudal peduncle depth $(6.3-7.4 \%)$, caudal peduncle length $(15.0-20.0 \%)$, body width at anus (8.7-11.5\%), body depth at anus (9.1-11.4\%), pre-dorsal fin length (43.7-47.4\%), prepectoral fin length (12.9-16.2\%), pre-anal fin length (74.3-79.3\%), pre-pelvic fin length (44.4-48.3\%), pelvic fin length (19.3-23.7\%), pectoral fin length (24.1-28.9\%) and body depth at dorsal (11.5-13.4\%).

Keywords: Balitora species, India, new fish, Western Ghats.

\section{INTRODUCTION}

Hill stream stone loaches of genus Balitora (Cypriniformes: Balitoridae) are distributed in South and South-East Asia and are currently represented by 18 species. Species of the genus Balitora inhabit clear and fast or moderately flowing streams and associated rivers in the mountain regions and are often found clinging to submerged rocks.

The first species described in this genus, Balitora brucei Gray, 1830, is distributed in northern and northeastern India. The other known species from India, Balitora mysorensis Hora, 1941 was described from the Cauvery River system. Other species in this genus $B$. eddsi

This article forms part of a special series on the Western Ghats of India, disseminating the results of work supported by the Critical Ecosystem Partnership Fund (CEPF), a joint initiative of l'Agence Française de Développement, Conservation International, the Global Environment Facility, the Government of Japan, the MacArthur Foundation and the World Bank. A fundamental goal of CEPF is to ensure civil society is engaged in biodiversity conservation. Implementation of the CEPF investment program in the Western Ghats is led and coordinated by the Ashoka Trust for Research in Ecology and the Environment (ATREE). 
Conway \& Mayden, 2010 is known from Nepal, $B$. burmanica Hora, 1932 from Myanmar, B. annamitica Kottelat, 1988 from Cambodia and B. meridionalis Kottelat, 1988 from Thailand. Balitora elongata Chen \& Li, 1985, B. kwangsiensis (Fang, 1930), B. lancangjiangensis (Zheng, 1980), B. longibarbata (Chen, 1982), B. ludongensis Liu \& Chen, 2012, B. nantingensis Chen et al. 2005, B. nujiangensis Zhang \& Zheng, 1983 and B. tchangi Zheng, 1982 are known from China, while B. haithanhi Nguyen, 2005, $B$. nigrocorpa Nguyen, 2005, B. vanlani Nguyen, 2005 and B. vanlongi Nguyen, 2005, from Vietnam. In the present communication, a new species of Balitora from the Krishna River system of northern Western Ghats of India is described.

\section{MATERIALS AND METHODS}

\section{Morphological characterization}

Counts and measurements generally follow Kottelat (1988) and Conway \& Mayden (2010). Measurements were taken point to point using dial calipers to the nearest $0.1 \mathrm{~mm}$. Body depth and body width were measured at dorsal fin origin (D) and at anus (A). Subunits of body are presented as percent of standard length (SL) and subunits of head are presented as percent of head length (HL). In the species description values for holotype are marked with asterisk $(*)$ and values in parentheses are ranges. If there is no variation in a character the values are not marked with asterisk. All pored lateral line scales were counted. The holotype and seven paratypes of the new species are deposited in the Zoological Survey of India, Western Regional Centre, Pune (ZSI-WRC) and one paratype in the museum collection of the Wildlife Information Liaison Development, Coimbatore (WILD).

\section{Comparative material}

Balitora mysorensis: Holotype, ZSI Kolkata F13512/1, Shivasamudram (approx. $12.294^{\circ} \mathrm{N}$ \& $\left.77.168^{\circ} \mathrm{E}, 530 \mathrm{~m}\right)$, Mysore, coll. B.S. Bhimachar; ZSIWRC P/3056, 2 exs., upstream of Shivasamudram falls near the town of Tirumakudalu Narasipura $\left(12.219^{\circ} \mathrm{N}\right.$ \& $\left.76.953^{\circ} \mathrm{E}\right)$, Mysore District, Karnataka, coll. Rahul Kumar (Biometric data in Appendix 3).

Balitora brucei: ZSI Kolkata F11092/1, 1 ex., Nong-piomg stream below Cherrapunji (approx. $\left.25.298^{\circ} \mathrm{N} \& 91.699^{\circ} \mathrm{E}, 1436 \mathrm{~m}\right)$, Khashi Hills, Assam, coll. S.L. Hora; ZSI-WRC P/2669, 1 ex., Jim Corbett National Park (approx. $29.576^{\circ} \mathrm{N} \& 78.819^{\circ} \mathrm{E}, 560 \mathrm{~m}$ ), Uttarakhand, coll. S. Chikane, June 2009. Additional information from Kottelat (1988).

Balitora burmanica: ZSI Kolkata F11034/1, 2 exs., syntypes, Meekalan (approx. $16.117^{\circ} \mathrm{N} \& 98.418^{\circ} \mathrm{E}$, 136m), Burma, specimens donated by Genova Museum. Additional information from Kottelat (1988).

Data for Balitora annamitica and B. meridionalis was taken from Kottelat (1988), for B. eddsi from Conway \& Mayden (2010), for B. nantingensis and Balitora nujiangensis from Chen et al. (2005), for Balitora ludongensis, B. kwangsiensis and $B$. longibarbata from Liu et al. (2012), for $B$. longibarbata and $B$. tchangi from Zheng et al. (1982), for B. elongata from Li \& Chen (1985), for $B$. lancangjiangensis from Zheng (1980). Descriptions of four species of Balitora described by Nguyen (2005) were not available, inspite of several attempts to contact the authors, therefore these species (viz. $B$. haithanhi, B. nigrocorpa, $B$. vanlani and $B$. vanlongi) are not considered in the diagnosis of the new species, however, these species are from Vietnam and are less likely to be conspecific.

\section{RESULTS}

\section{Taxonomy}

\section{Balitora laticauda sp. nov.}

(Images 1, 2a, 2b, 3a, 4a, 4b and Table 1)

\section{Type material}

Holotype: 10.i.2012, 69.5mm SL, Stream of Krishna River drainage at Venegaon Village near Krishna River bridge $\left(17.499^{\circ} \mathrm{N} \& 74.118^{\circ} \mathrm{E}, 590 \mathrm{~m}\right)$, Satara District, Maharashtra, India, coll. Sunil Bhoite, ZSI-WRC P/2848.

Paratypes: 10.i.2012, 1 ex., 79.8mm SL, Venegaon Village near Krishna River bridge $\left(17.499^{\circ} \mathrm{N}\right.$ \& $\left.74.118^{\circ} \mathrm{E}, 590 \mathrm{~m}\right)$, Satara District, Maharashtra, India, coll. Sunil Bhoite, ZSI-WRC P/2849; 10.i.2012, 1 ex., 63.6mm SL, Venegaon Village near Krishna River bridge $\left(17.499^{\circ} \mathrm{N} \& 74.118^{\circ} \mathrm{E}, 590 \mathrm{~m}\right)$, Satara District, Maharashtra, India, coll. Sunil Bhoite, ZSI-WRC $\mathrm{P} / 2850$; 8.xii.2009, 2 exs., $59.7 \mathrm{~mm}$ and $62.7 \mathrm{~mm} \mathrm{SL}$, Nagthane Village on Urmodi River $\left(17.568^{\circ} \mathrm{N} \&\right.$ 


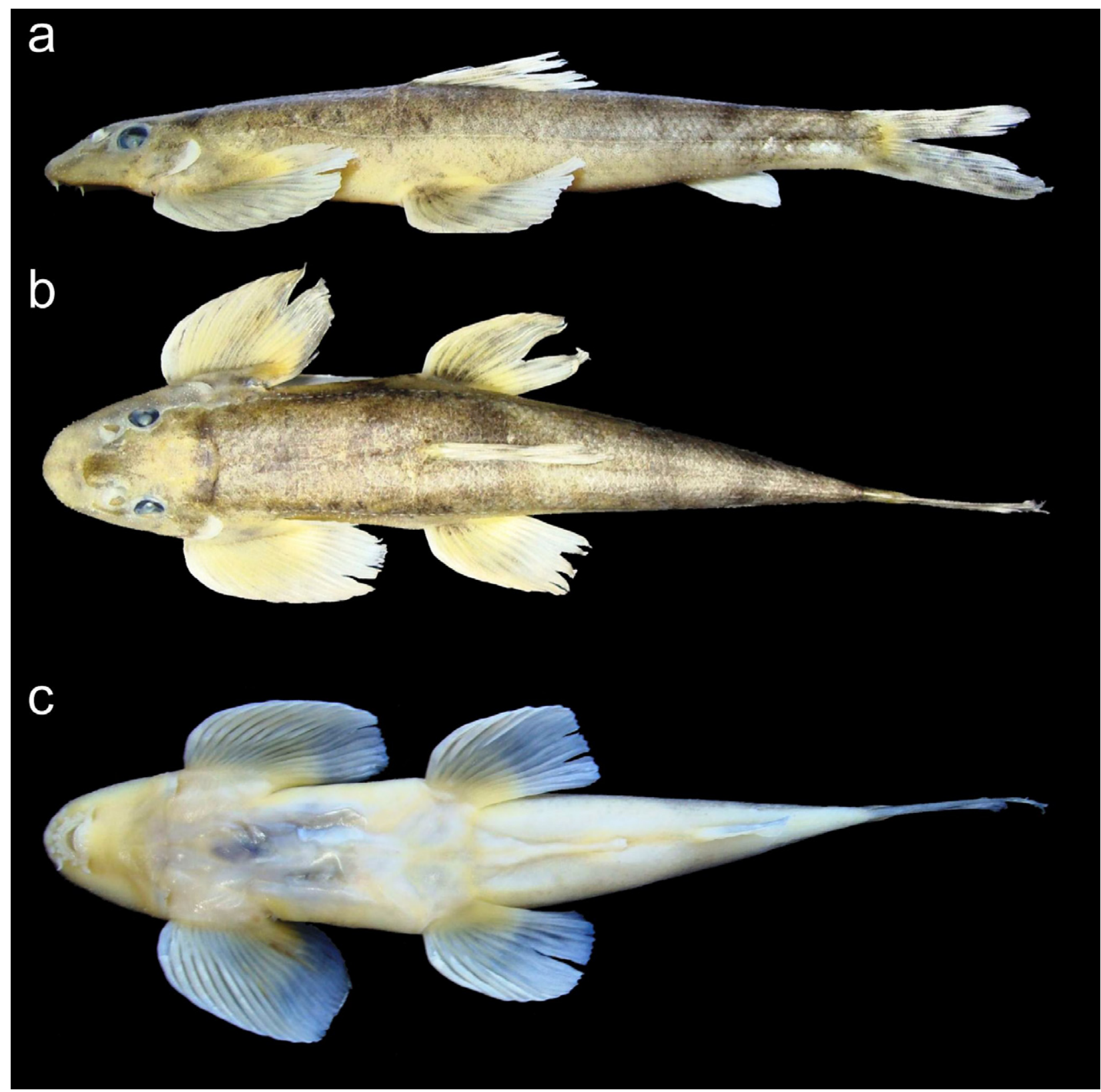

Image 1. Holotype of Balitora laticauda sp. nov., holotype (ZSI-WRC P/2848) in (a) lateral view, (b) dorsal view and (c) ventral view.

$\left.74.053^{\circ} \mathrm{E}, 606 \mathrm{~m}\right)$, a tributary of Krishna River in Satara District, Maharashtra State, India, coll. Sunil Bhoite, ZSI-WRC P/2851; 10.i.2012, 1 ex., 48.7mm SL, Venegaon Village near Krishna River bridge $\left(17.499^{\circ} \mathrm{N}\right.$ $\left.\& 74.118^{\circ} \mathrm{E}, 590 \mathrm{~m}\right)$, Satara District, Maharashtra, India, coll. Sunil Bhoite, WILD-12-PIS-019; 8.xii.2009, 1 ex., $61.5 \mathrm{~mm}$ SL, Nagthane Village on Urmodi River $\left(17.568^{\circ} \mathrm{N} \& 74.053^{\circ} \mathrm{E}, 606 \mathrm{~m}\right)$, a tributary of Krishna River in Satara District, Maharashtra State, India, coll. Sunil Bhoite, ZSI-WRC P/3058; 2.v.2012, 2 ex., $54 \mathrm{~mm}$ and $84.4 \mathrm{~mm}$ SL, Khodashi village below
Khodshi Dam $\left(17.308^{\circ} \mathrm{N} \& 74.167^{\circ} \mathrm{E}, 562 \mathrm{~m}\right)$, Krishna River, in Satara District, Maharashtra State, India, coll. Madhavi Chavan, ZSI-WRC P/3057.

\section{Diagnosis}

Balitora laticauda sp. nov. differs from closely related species $B$. mysorensis based on seven most prominent characters viz. 10 transverse bands on the dorsal surface (vs. 7), caudal peduncle length versus depth ratio 2.21-2.89 (vs. 2.95-3.30), body depth at anus 9.1-11.4\%SL (vs. 8.4-9.0\%SL), depth of caudal 


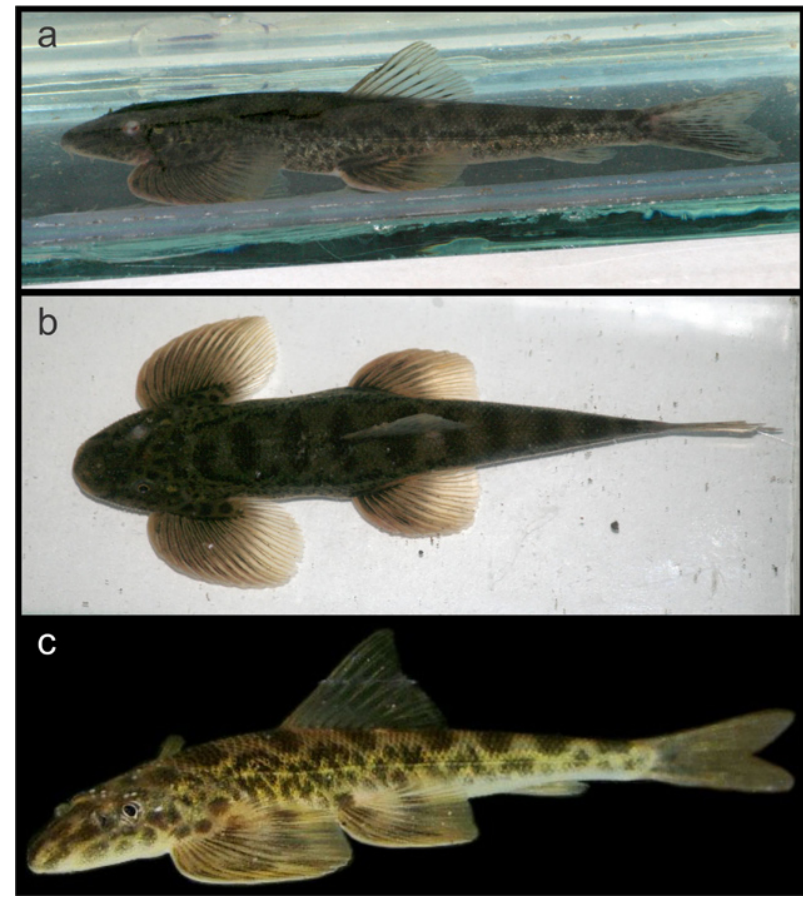

Image 2. Balitora laticauda sp. nov., holotype (ZSI-WRC $P / 2848$ ) in life showing (a) lateral and (b) dorsal view and B. mysorensis (ZSI-WRC P/3056) in life (c). Note the difference in the number of dorsal bands.
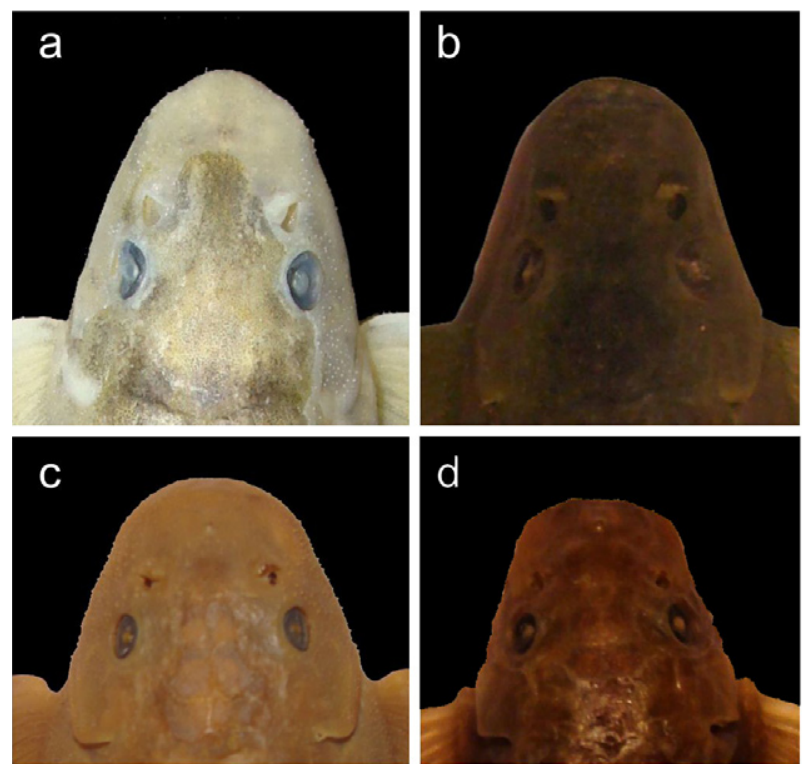

Image 3. Dorsal view of head of (a) Balitora laticauda sp. nov., holotype (P/2848), (b) B. mysorensis, holotype (F13512/1), (c) B. brucei (F11092/1) and (d) B. burmanica, syntype (F11032/1).

peduncle $6.3-7.4 \% \mathrm{SL}$ (vs. 5. - 5.4\%SL), body width at anus $8.7-11.5 \% \mathrm{SL}$ (vs. 7.8-8.8\%SL), length of lower caudal lobe $16.1-24.3 \% \mathrm{SL}$ (vs. 24.7-26.5 $\% \mathrm{SL})$ and length of median caudal ray (12.3-16.5
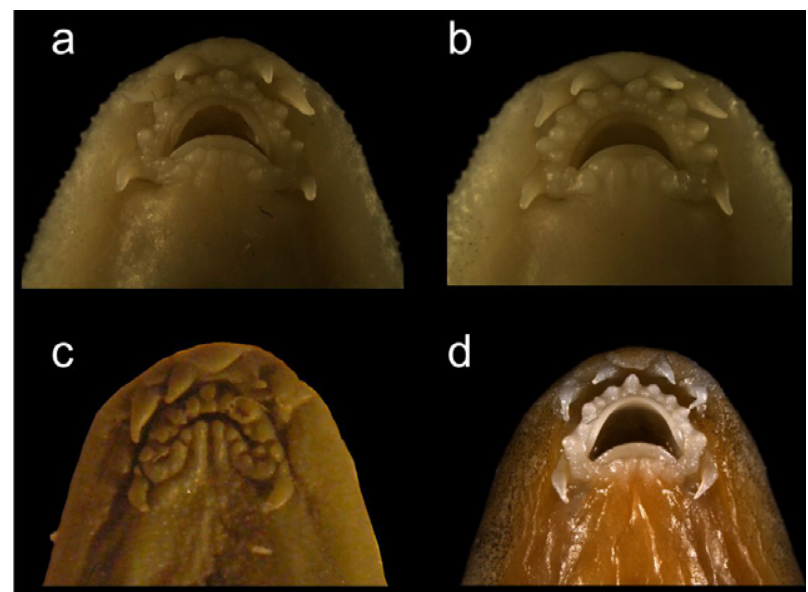

d

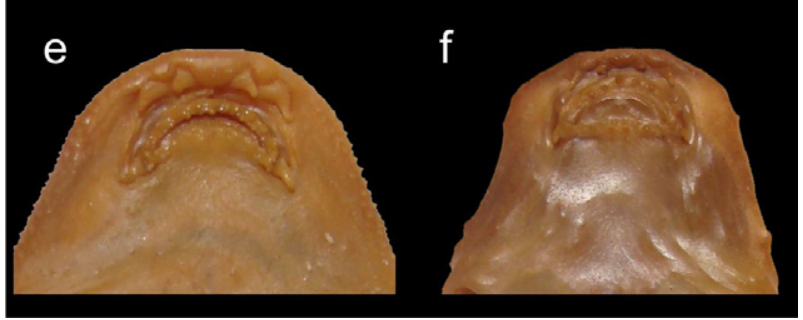

Image 4. Ventral view of head of (a) Balitora laticauda sp. nov., holotype (P/2848), (b) B. laticauda sp. nov., paratype (P/2849), (c) B. mysorensis, holotype (F13512/1), (d) B. mysorensis (ZSI-WRC P/3056), (e) B. brucei (F11092/1) and (f) B. burmanica, syntype (F11032/1).

\%SL (vs. 11.0-11.3 \%SL). The new species differs from all other known species in this genus based on a combination of characters including 66-68 lateral line scales, $8-9$ simple rays in pectoral fin, two simple rays in the pelvic fin and pectoral fin not surpassing pelvic fin base. It also differs from other species in the ratios such as caudal peduncle length to depth (2.21-2.89), standard length to body depth (7.48-8.72), head length to head depth (2.11-2.50), head length to interorbital distance (2.20-2.96) and head width to gape of mouth (3.12-4.78). As percent of standard length, $B$. laticauda sp. nov. differs from other species by having caudal peduncle depth $6.3-7.4 \%$ SL; caudal peduncle length $15.0-20.0 \% \mathrm{SL}$; body width at anus 8.7-11.5 $\%$ SL; body depth at anus 9.1-11.4 \%SL; pre-dorsal fin length 43.7-47.4\%SL; pre-pectoral fin length $12.9-16.2 \% \mathrm{SL}$; pre-anal fin length $74.3-79.3 \% \mathrm{SL}$; pre-pelvic fin length $44.4-48.3 \% \mathrm{SL}$; pelvic fin length 19.3-23.7 \%SL; pectoral fin length 24.1-28.9 \%SL; body depth at dorsal 11.5-13.4\%SL; head depth 42.1$47.3 \% \mathrm{HL}$; eye diameter $10.8-20.7 \% \mathrm{HL}$ and gape of mouth $16.9-27.1 \%$ head width. 
Table 1. Morphometric and meristic characters of Balitora laticauda sp. nov. and B. mysorensis

\begin{tabular}{|c|c|c|c|c|c|}
\hline \multirow{3}{*}{ Morphometry } & \multicolumn{3}{|c|}{ Balitora laticauda sp. nov. } & \multirow{2}{*}{\multicolumn{2}{|c|}{$\begin{array}{l}\text { Balitora mysorensis } \\
\text { Holotype+2 topotypes }\end{array}$}} \\
\hline & \multirow{2}{*}{ Holotype } & \multicolumn{2}{|c|}{ Paratypes $(n=8)$} & & \\
\hline & & Mean (sd) & Range & Mean (sd) & Range \\
\hline Standard length (mm) & 69.5 & $64.3(12.1)$ & $(48.7-84.4)$ & $58.1(16.7)$ & $(38.8-68.3)$ \\
\hline Total length (mm) & 84.4 & $77.5(13.5)$ & $(59.2-98.3)$ & $84.0(0.9)$ & $(83.4-84.7)$ \\
\hline \multicolumn{6}{|l|}{$\% S L$} \\
\hline Head length & 21.9 & $20.8(0.6)$ & $(20.1-21.9)$ & $20.8(1.8)$ & $(19.6-22.9)$ \\
\hline Dorsal head length & 21.6 & $20.6(1.4)$ & $(18.4-22.3)$ & $19.0(1.0)$ & $(18.4-19.7)$ \\
\hline Predorsal length & 45.2 & $46.1(1.2)$ & $(43.7-47.4)$ & $44.5(0.3)$ & $(44.2-44.7)$ \\
\hline Dorsal to caudal distance & 55.7 & $55.6(1.2)$ & $(53.6-57.2)$ & $56.2(0.6)$ & $(55.8-56.6)$ \\
\hline Prepectoral fin length & 16.2 & $14.8(1.1)$ & $(13.0-16.1)$ & $15.3(0.4)$ & $(15.1-15.6)$ \\
\hline Prepelvic length & 44.4 & $46.6(1.2)$ & $(44.8-48.3)$ & $46.2(0.3)$ & $(46.0-46.4)$ \\
\hline Preanus length & 68.1 & $70.1(1.4)$ & $(68.7-73.1)$ & $70.8(0.8)$ & $(70.3-71.4)$ \\
\hline Preanal length & 77.0 & $77.4(1.6)$ & $(74.3-79.3)$ & $78.8(0.4)$ & $(78.5-79.1)$ \\
\hline Ventral fin to anus distance & 24.3 & $25.1(1.5)$ & $(22.6-27.5)$ & $25.0(0.8)$ & $(24.4-25.5)$ \\
\hline Anal fin to anus distance & 7.8 & $6.7(0.5)$ & $(5.7-7.3)$ & $7.7(1.1)$ & $(6.9-8.5)$ \\
\hline Body depth (D) & 13.4 & $12.2(0.6)$ & $(11.5-13.1)$ & $11.7(1.2)$ & $(11.0-13.1)$ \\
\hline Body depth (A) & 11.1 & $10.1(0.8)$ & $(9.1-11.4)$ & $8.7(0.4)$ & $(8.4-9.0)$ \\
\hline Depth of caudal peduncle & 7.0 & $7.0(0.4)$ & $(6.3-7.4)$ & $5.2(0.2)$ & $(5.1-5.4)$ \\
\hline Length of caudal peduncle & 17.5 & $17.7(1.8)$ & $(15.0-20.0)$ & $16.1(1.0)$ & $(15.2-17.3)$ \\
\hline Body width (D) & 17.9 & $18.1(1.3)$ & $(16.3-19.7)$ & $16.7(0.7)$ & $(16.0-17.4)$ \\
\hline Body width (A) & 12.0 & $9.7(0.9)$ & $(8.7-11.5)$ & $8.3(0.7)$ & $(7.8-8.8)$ \\
\hline Height of dorsal fin & 18.5 & $18.8(1.3)$ & $(16.3-20.5)$ & $16.8(3.5)$ & $(13.9-20.6)$ \\
\hline Dorsal fin base & 15.1 & $15.1(0.7)$ & $(13.9-16.1)$ & $14.8(2.5)$ & $(13.0-16.6)$ \\
\hline Length of upper caudal lobe & 18.0 & $19.3(1.8)$ & $(15.7-21.0)$ & $18.4(1.7)$ & $(17.2-19.6)$ \\
\hline Length of lower caudal lobe & 24.0 & $21.5(2.8)$ & $(16.1-24.3)$ & $25.6(1.3)$ & $(24.7-26.5)$ \\
\hline Length of median caudal rays & 14.6 & $14.1(1.4)$ & $(12.3-16.5)$ & $11.2(0.2)$ & $(11.0-11.3)$ \\
\hline Height of anal fin & 11.6 & $12.8(1.1)$ & $(11.3-13.9)$ & $13.6(3.8)$ & $(11.3-18.0)$ \\
\hline Anal fin base & 6.5 & $6.1(0.6)$ & $(5.2-7.3)$ & $6.3(0.2)$ & $(6.2-6.4)$ \\
\hline Length of pelvic fin & 21.7 & $21.5(1.2)$ & $(19.3-23.7)$ & $21.6(1.2)$ & $(20.6-22.9)$ \\
\hline Length of pectoral fin & 24.1 & $26.4(1.5)$ & $(24.4-28.9)$ & $25.1(1.2)$ & $(23.9-26.3)$ \\
\hline \multicolumn{6}{|l|}{$\% \mathrm{HL}$} \\
\hline Head depth at eye & 38.0 & $37.4(1.9)$ & $(34.5-39.6)$ & $39.8(1.0)$ & $(39.0-40.5)$ \\
\hline Head depth at nape & 46.0 & $44.2(2.4)$ & $(40.9-47.3)$ & $44.8(0.7)$ & $(44.0-45.5)$ \\
\hline Head width (at nares) & 66.1 & $69.5(4.1)$ & $(63.6-75.2)$ & $63.2(1.1)$ & $(62.5-64.0)$ \\
\hline Maximum head width & 79.3 & $87.4(5.7)$ & $(77.7-93.3)$ & $75.8(4.5)$ & $(70.8-79.4)$ \\
\hline Eye diameter & 13.2 & $15.5(2.8)$ & $(10.8-20.7)$ & $15.0(2.6)$ & $(13.3-18.0)$ \\
\hline Interorbital width & 39.5 & $39.8(4.0)$ & $(33.7-45.4)$ & $35.0(2.1)$ & $(32.6-36.2)$ \\
\hline Snout length & 58.2 & $56.3(3.2)$ & $(52.7-61.8)$ & $61.2(1.3)$ & $(59.8-62.1)$ \\
\hline Gape of mouth & 21.7 & $23.3(3.2)$ & $(16.9-27.1)$ & $19.8(1.2)$ & $(18.9-20.6)$ \\
\hline \multicolumn{6}{|l|}{ Meristics } \\
\hline D & iii, 8 & & iii, 7-8 & & iii, 8-9 \\
\hline A & iii, 5 & & iii, 5 & & ii, 5 \\
\hline $\mathrm{P}$ & ix, 10 & & viii-ix, 10-11 & & viii-ix, 10-12 \\
\hline V & ii, 9 & & ii, 8-9 & & ii, 8-9 \\
\hline Lateral line scales & 67 & & $66-68$ & & $68-69$ \\
\hline Lateral line to ventral fin scales & 8 & & $6-9$ & & 6 \\
\hline Lateral line to dorsal fin scales & 8 & & $8-9$ & & 9 \\
\hline Predorsal scales & 20 & & $19-25$ & & 21 \\
\hline
\end{tabular}




\section{DESCRIPTION}

Morphometric data and meristic counts are listed in Table 1. General body shape as in Image 1. Coloration of live specimen as in Image 2. Dorsal and ventral view of head as in Images $3 a$ and $4 a, b$ respectively. Appendix 1 provides general body structure of paratypes from a different locality than holotype. Appendix 2 provides biometric data of all the type material.

Head depressed, longer than broad, studded with tubercles, more prominent on lateral margin of dorsal side. Tubercles prominent on cheeks, snout, lateral and ventral surface of head up to base of pectoral fin, between orbits with a distinct row on dorsal margin of eye, encircling the eyes. Eyes small, dorso-laterally positioned, not visible from underside of head, closer to operculum than to snout. Snout oblique and rounded. A skin flap divides nostril. Mouth inferior, deep groove between rostral fold and upper lip. Gape of mouth about half of head width at nares. Barbels three pairs, two rostral and one maxillary. Upper lip encircled with two rows of uneven papillae; first row having small papillae $\left(16^{*}\right.$ in number) positioned continuously end to end, second row having large papillae ( $8 *$ in number) positioned discontinuously with wide interspaces. Lower lip with $8 *$ large papillae, two in the middle are elongated. Gill opening extending from level of posterior border of eye to middle point of pectoral-fin base.

Body dorso-ventrally flattened before dorsal fin origin, become laterally flattened posterior to dorsal fin. Dorsal profile of body convex, shows rapid increase from snout to nostril, becomes flattened till nape, increases gradually till origin of dorsal fin, decreases gradually till end of caudal peduncle. Lateral line complete. Slightly bent towards dorsal surface at the posterior border of pectoral fin. Lateral line scales $67^{*}(66-68)$. Ventral profile flat upto anal fin origin gradually descends till caudal peduncle end. Chest naked without scales. On ventral surface, scales present posterior to anal opening till caudal end. Scales anterior to anal opening till posterior of pelvic fin base indistinct. Body deepest at dorsal fin origin. Body width more than body depth at both dorsal fin origin and anus.

Outer margin of dorsal fin straight. Dorsal fin originates exactly opposite to pelvic fin origin, closer to tip of snout than end of caudal peduncle; pelvic fin length lesser than head length; with three simple and eight branched rays, last branched ray bifurcates at base. Paired fins horizontally placed. Pectoral fin elongated, longer than head, its origin slightly behind posterior border of eye. Anterior margin of first pectoral fin thickened and curved. Posterior profile of pectoral fin straight with large gap between posterior border and pelvic fin origin; with ix* (viii-ix) simple rays and $10 *(10-11)$ branched rays. Pelvic fin equal to or slightly shorter than head; fin origin closer to snout tip than caudal peduncle end; with two simple rays and 9* (8-9) branched rays. Thickened pads of skin along ventral surface of the anteriormost pairedfin rays, first $9^{*}(8-9)$ in case of pectoral fin, first four in case of pelvic fins. Anal fin with three simple and five branched rays with last branched ray bifurcating at base. Caudal fin emarginate, lower lobe longer than upper. Caudal peduncle slender, length 2.21-2.89 times its depth. Maximum size up to $84.4 \mathrm{~mm} \mathrm{SL}$ and 98.3mm TL.

Color pattern (fresh, Image 2): Dorsal surface grey with ten dark brown vertical bands behind occiput to base of caudal fin. Ventral surface pale yellow to white, laterally dark grey above lateral line and becomes faint from lateral line to ventral surface. A mid-lateral row of very irregular dark brown spots between opercle and middle of caudal fin base. Below the lateral line small irregular dark brown blotches scattered randomly on lateral surface of the body. A faint brown stripe extending from occiput to end of caudal base. Parts of head grayish-brown above, pale yellow below; with irregular brown patches on dorsal surface. Dorsal side of pectoral fin base with 3-4 dark brown spots. Dorsal and anal fins with light brown markings on centre of fin rays which appear to be oblique band. Pectoral and pelvic fins with dark brown markings extending from its base to middle of fin rays, hyaline distally. Caudal fin with irregular dark brown spots along midway and hyaline at tips and posterior margins.

Color pattern (preserved): Two specimens (Holotype ZSI Pune P/2848 and paratype ZSI Pune $\mathrm{P} / 2849$ ), which were originally preserved in formalin before finally transferred in the alcohol, have lost their original color pattern. However, the other paratypes were preserved directly in alcohol and have retained their color pattern as in the live specimens. 


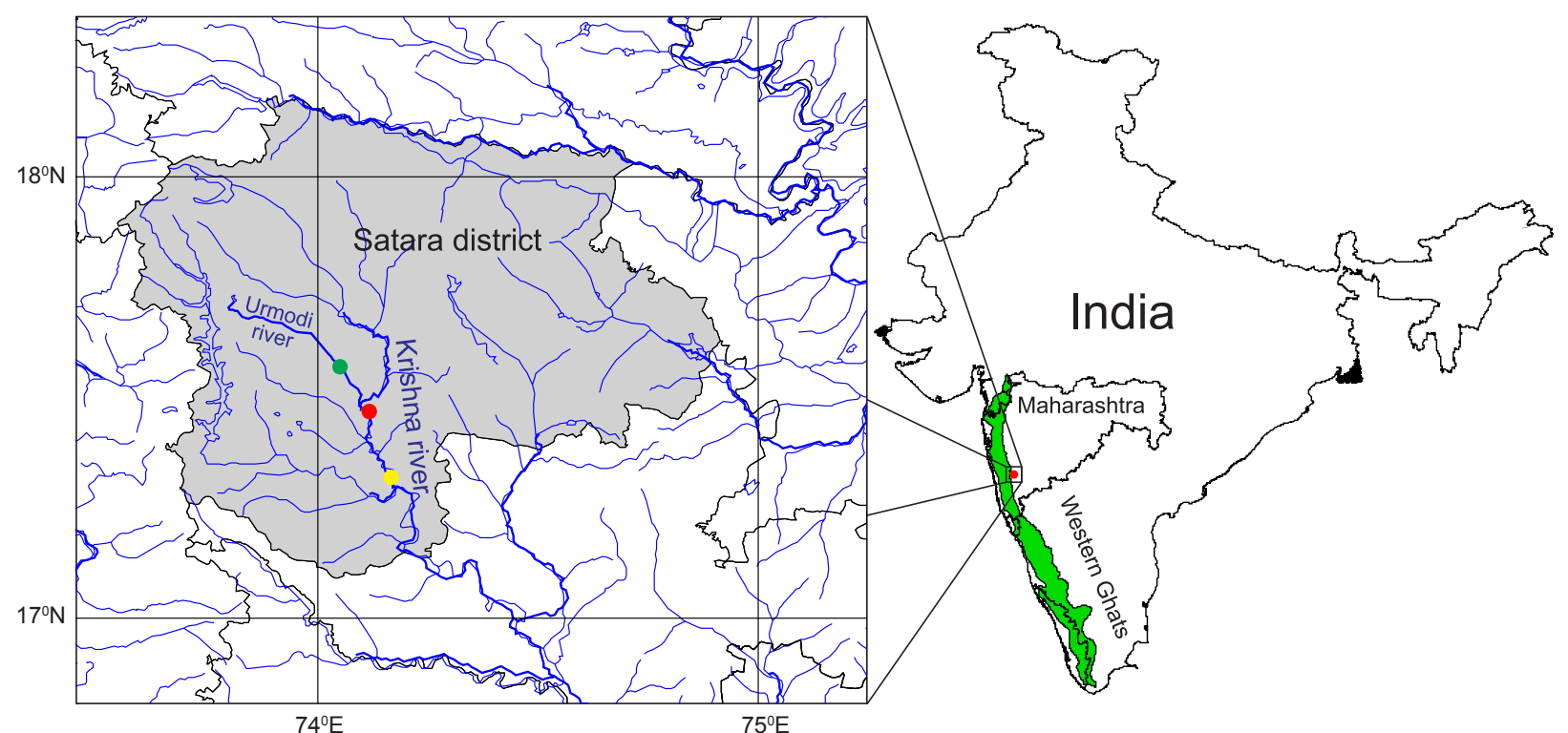

Figure 1. Distribution of Balitora laticauda sp. nov. Red solid circle is the type locality for the holotype (ZSI-WRC P/2848) and paratypes ZSI-WRC P/2849, P/2850 and WILD-12-PIS-019, while green solid circle is locality for paratypes ZSI-WRC P/2851, ZSI-WRC P/3058 and yellow solid circle is the locality for paratype ZSI-WRC P/3057.

\section{Etymology}

Specific name "laticauda" is derived from Latin 'latus' meaning 'broad' and 'cauda' meaning 'tail' and refers to the deeper caudal peduncle of the species as compared to two geographically closely related species, Balitora mysorensis and B. brucei.

\section{Distribution}

Known from the type localities, Venegaon Village near Krishna River bridge, Nagthane Village on Urmodi River and Khodashi Village below Khodshi Dam on Krishna River, Satara District, Maharashtra State, India (Fig. 1).

\section{Habitat}

The fish mostly lives in streams with clear and swift current of water, rocky bottom, consisting of gravel, cobbles or large rocks associated with other species viz. Rasbora daniconius, Pethia ticto, Puntius sahyadriensis, Hypselobarbus kolus, Tor khudree, Mastacembelus armatus, Channa gachua and Lepidocephalichthys thermalis. There are no specific threats observed in the vicinity of type localities. However, potential threat to the habitat include severe sand mining upstream of type locality and agricultural run-off entering into the river. Habitat at the type locality is shown in Image 5.

\section{Other remarks}

Local name (in Marathi language) of the species is Palmas $(\mathrm{Pal}=$ lizard, mas $=$ fish; lizard-fish $)$ because of its general appearance of a lizard and habit of clinging to the rocks in streams and river.

\section{Common name}

We suggest 'Palmas Stone Loach' as a common name for the speceis.

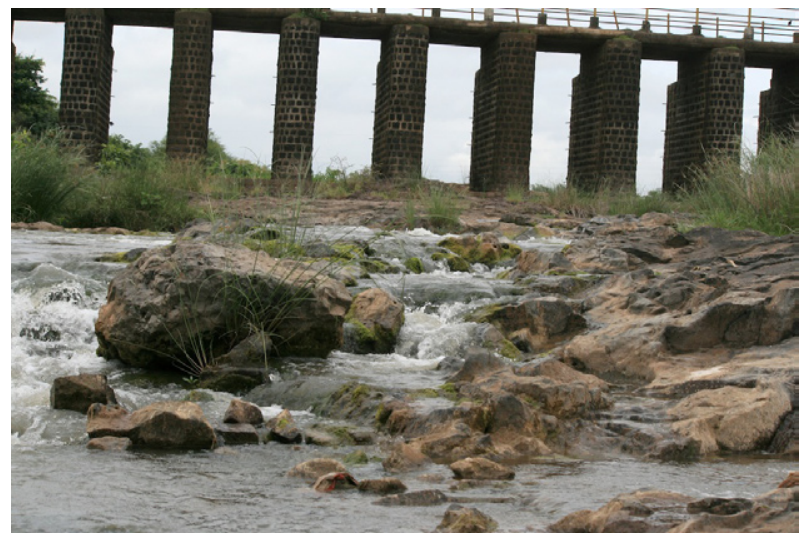

Image 5. Stream at Venegaon Village, type locality of Balitora laticauda sp. nov., showing its habitat 


\section{DISCUSSION}

Kalawar \& Kelkar (1956) included Balitora shimogensis Silas \& Kalawar in their list of species from Panchaganga River, a tributary of Krishna River in northern Western Ghats of Kolhapur District, Maharashtra with a remark that the species will be described elsewhere. However, to our knowledge, till date the species has not been described and Kottelat (1988) considered it as nomen nudum for lack of any distinguishing characters and tentatively referred to it as a synonym of $B$. mysorensis. Since Panchaganga River is also a tributary of Krishna River system and lies just downstream of the type locality of $B$. laticauda sp. nov., it is quite possible that Kalawar \& Kelkar (1956) might have actually referred to B. laticauda sp. nov. However, in the absence of any description and diagnostic characters of B. shimogensis, it is impossible to investigate this further.

Balitora laticauda sp. nov. differs from its very closely related species B. mysorensis, in terms of both geographical distribution and general body structure, based the following characters. Balitora laticauda sp. nov., as compared to B. mysorensis, has higher ratio of caudal peduncle length versus depth (2.21-2.89 vs. 2.95-3.3), higher depth of body at anus (9.1-11.4 \%SL vs. 8.4-9.0 \%SL), higher depth of caudal peduncle (6.3-7.4 \%SL vs. 5.1-5.4\%SL), higher body width at anus $(8.7-11.5 \%$ SL vs. $7.8-8.8$ $\% \mathrm{SL})$, shorter length of lower caudal lobe (16.1-24.3 $\%$ SL vs. $24.7-26.5 \% \mathrm{SL}$ ) and higher length of median caudal ray (12.3-16.5 \%SL vs. $11.0-11.3 \% \mathrm{SL})$. However, the most striking differences which separate these two species are- (a) more number of transverse bands on the dorsal surface of $B$. laticauda sp. nov. (10) as compared to B. mysorensis (7), (b) lower lobe of caudal fin much shorter in B. laticauda sp. nov. as compared to B. mysorensis, (c) two rows of distinct and prominent papillae encircling upper lip where the proximal row has small papillae while distal row has large papillae in the case of B. laticauda sp. nov. (Image $3 \mathrm{a}$ and $3 \mathrm{~b}$ ) versus less distinct rows of large and smaller papillae in case of B. mysorensis (Image $3 \mathrm{c}$ and $3 \mathrm{~d}$ ), and (d) more stout caudal peduncle in $B$. laticauda sp. nov. as compared to B. mysorensis. Our comparison of $B$. laticauda sp. nov. and B. mysorensis is based on the study of $B$. mysorensis type material and type description given by Hora (1941) as well as two specimens collected from the type locality of $B$. mysorensis. Note that the holotype of B. mysorensis is in a very bad condition so the morphometric data we used is compiled from the original description by Hora (1941). Apart from distribution of the two species in different river systems, drastic differences between the new species and B. mysorensis suggest that they are not conspecific.

While comparing Balitora laticauda sp. nov. with $B$. mysorensis, we have not considered the description of B. mysorensis provided by Menon (1987), as it is based on two specimens collected from Tungabhadra River, a tributary of Krishna River system in Karnataka, while the type of B. mysorensis is known from Cauvery River system in southern India. Even though Menon (1987) has mentioned that the type material of B. mysorensis was examined, he has provided no information about the type and has not provided any comparative account between the specimens from Tungabhadra and Cauvery rivers. It is therefore essential to investigate whether the B. mysorensis specimens studied in Menon (1987) are really conspecific with $B$. mysorensis sensu stricto. Balitora laticauda sp. nov. differs from the description of B. mysorensis given in Menon (1987) by having smaller head length (20.1-21.9\%SL vs. 23.30-24.75 \%SL), higher head depth (42.1-47.3\%HL vs. 32.0 $41.66 \% \mathrm{HL}$ ) and more number of lateral line scales (66-68 vs. 64-65).

Among the other species of Balitora, which are geographically closer to the new species, $B$. laticauda sp. nov. differs from $B$. brucei in deeper caudal peduncle $(6.3-7.4 \% \mathrm{SL}$ vs. $5.1-5.8 \% \mathrm{SL})$, broader body width at anus (8.7-12.0 \%SL vs. $5.4-8.1 \% \mathrm{SL})$, lower ratio of caudal peduncle length to depth (2.212.89 vs. $3.20-4.00$ ) and more number of lateral line scales (66-68 vs. 61-66). Balitora laticauda sp. nov. differs from $B$. burmanica in deeper caudal peduncle (6.3-7.4\%SL vs. 5.1-6.3\%SL), broader body width at anus (8.7-12.0\%SL vs. $6.4-7.4 \% \mathrm{SL})$, lower ratio of caudal peduncle length to depth (2.21-2.89 vs. 3.00$4.00)$ and more number of lateral line scales (66-68 vs. 62-65). Further, both B. brucei and B. burmanica have broader head (Image 3 ) and completely different structure of mouth as compared to B. laticauda sp. nov. (Image 4).

Balitora laticauda sp. nov. differs from B. eddsi of Nepal in shorter pre-dorsal length (43.7-47.4\%SL vs. 48.1-50.4\%SL), longer pre-anal distance (74.3-79.3 
\%SL vs. 68.5-70.1\%SL), deeper body at anus (9.1$11.4 \% \mathrm{SL}$ vs. $6.8-8.2 \% \mathrm{SL}$ ), deeper caudal peduncle (6.3-7.4 \%SL vs. 5.4-5.7 \%SL), longer caudal peduncle (15.0-20.0 \%SL vs. 22.0-23.2\%SL), longer pelvic fin (19.3-23.7 \%SL vs. $12.8-14.0 \% \mathrm{SL})$, longer pectoral fin (24.1-28.9 \%SL vs. 19.6-21.7\%SL) and lower ratio of caudal peduncle length to depth (2.212.89 vs. $4.10-4.20)$.

With respect to other species of genus Balitora, B. laticauda sp. nov. differs from B. annamitica in shorter pre-anus length $(68.1-73.1 \%$ SL vs. $73.2-75.2$ $\% \mathrm{SL})$, broader body width at anus $(8.7-12.0 \% \mathrm{SL}$ vs. $7.0-7.8 \% \mathrm{SL})$, shorter pelvic fin $(19.3-23.7 \% \mathrm{SL}$ vs. $23.4-24.4 \% \mathrm{SL}$ ) and more number of lateral line scales (66-68 vs. 62-64). Balitora laticauda sp. nov. differs from $B$. meridionalis in shorter pre-pelvic length (44.4-48.3\%SL vs. 48.1-48.9\%SL), broader body width at anus (8.7-12.0 \%SL vs. $8.1-8.5 \% \mathrm{SL})$, shorter pelvic fin (19.3-23.7 \%SL vs. $22.3-22.4$ $\% \mathrm{SL}$ ) and more number of lateral line scales (66-68 vs. 61-62). Balitora laticauda sp. nov. differs from $B$. nantingensis in shorter pre-pectoral fin length (12.9-16.2 \%SL vs. $23.3-26.3 \% \mathrm{SL}$ ), more number of lateral line scales (66-68 vs. 62-64) and more number of transverse bands on the dorsal surface (10 vs. 6). Balitora laticauda sp. nov. differs from $B$. ludogensis in shallower body depth (11.5-13.4\%SL vs. 15.0$19.5 \% \mathrm{SL})$, flatter head (42.1-47.3\%HL vs. $51.2-67.2$ $\% \mathrm{HL}$ ) and less number of lateral line scales (66-68 vs. 69-74). Balitora laticauda sp. nov. differs from B. kwangsiensis in shallower flatter head (42.1-47.3 $\% \mathrm{HL}$ vs. 47.7.2-57.6 \%HL), smaller eye diameter $(10.8-20.7 \% \mathrm{HL}$ vs. $19.7-21.4 \% \mathrm{HL})$ and higher ratio of caudal peduncle depth to length ratio (62.6$89.6 \% \mathrm{HL}$ vs. $37.8-50.9 \% \mathrm{SL}$ ). Balitora laticauda sp. nov. differs from $B$. longibarbata in shallower body depth (11.5-13.4\%SL vs. 15.5-17.2\%SL), flatter head (42.1-47.3\%SL vs. 50.5-60.3\%SL) and less number of lateral line scales (66-68 vs. 73-77). Balitora laticauda sp. nov. differs from $B$. tchangi in less number of lateral line scales (66-68 vs. 71) and higher ratio of head to interorbital distance (2.2-2.96 vs. 2). Balitora laticauda sp. nov. differs from $B$. lancangjiangensis higher ratios of standard length to body depth (7.48-8.72 vs. 5.91-6.72), head length to head depth (2.11-2.50 vs. 1.72-2.00) and head width to gape of mouth (3.12-4.78 vs. 2.33-2.85). Balitora laticauda sp. nov. differs from B. elongata in having less number of pectoral fin simple rays (viii-ix vs. $\mathrm{x}$-xi) and less number of pelvic fin simple rays (ii vs. iii-iv). Balitora laticauda sp. nov. differs from B. nujiangensis in having less number of pelvic fin simple rays (ii vs. iii) and pectoral fin not surpassing pelvic fin base (vs. surpassing).

The Western Ghats of India is rich in freshwater fish diversity with about 290 known species, $65 \%$ of which are endemic to the river systems originating from the Western Ghats (Dahanukar et al. 2011), while about $40 \%$ are endemic to the Western Ghats mountain ranges (Dahanukar et al. 2004). Recent updates in the IUCN Redlist has suggested that out of the total 290 species known from the Western Ghats, $37 \%$ fall under the threatened categories - Critically Endangered, Endangered or Vulnerable, owing to several anthropogenic threats including pollution, biological resource use (food fish and aquarium trade), invasive species, residential and commercial developments and natural system modification (Dahanukar et al. 2011). While freshwater fish diversity is subjected to severe threats, new species are still being discovered from this region suggesting that our understanding of the diversity in this region is still far from being complete. With increasing consciousness regarding conservation of flora and fauna of biodiversity hotspots such as Western Ghats, description of this new species bolsters the views expressed by Dahanukar et al. (2011) and Raghavan et al. (2012) that taxonomic work on the fish fauna of the Western Ghats is essential to understand the unknown diversity of this region, so as to design and implement potent conservation action plans.

\section{REFERENCES}

Chen, X.-Y., G.-H. Cui \& J.-X. Yang (2005). Balitora nantingensis (Teleostei: Balitoridae), a new hill stream loach from Salween drainage in Yunnan, southwestern China. The Raffles Bulletin of Zoology Supplement 13: 21-26.

Conway, K.W. \& R.L. Mayden (2010). Balitora eddsi, a new species of hill stream loach (Ostariophysi: Balitoridae) from Nepal. Journal of Fish Biology 76(6): 1466-1473.

Dahanukar, N., R. Raghavan, A. Ali, R. Abraham \& C.P. Shaji (2011). The status and distribution of freshwater fishes of the Western Ghats. Chapter 3, pp. 21-48. In: Molur, S., K.G. Smith, B.A. Daniel \& W.R.T. Darwall (compilers), The Status and Distribution of Freshwater Biodiversity in The Western Ghats, India. IUCN, Cambridge, UK and Gland, 


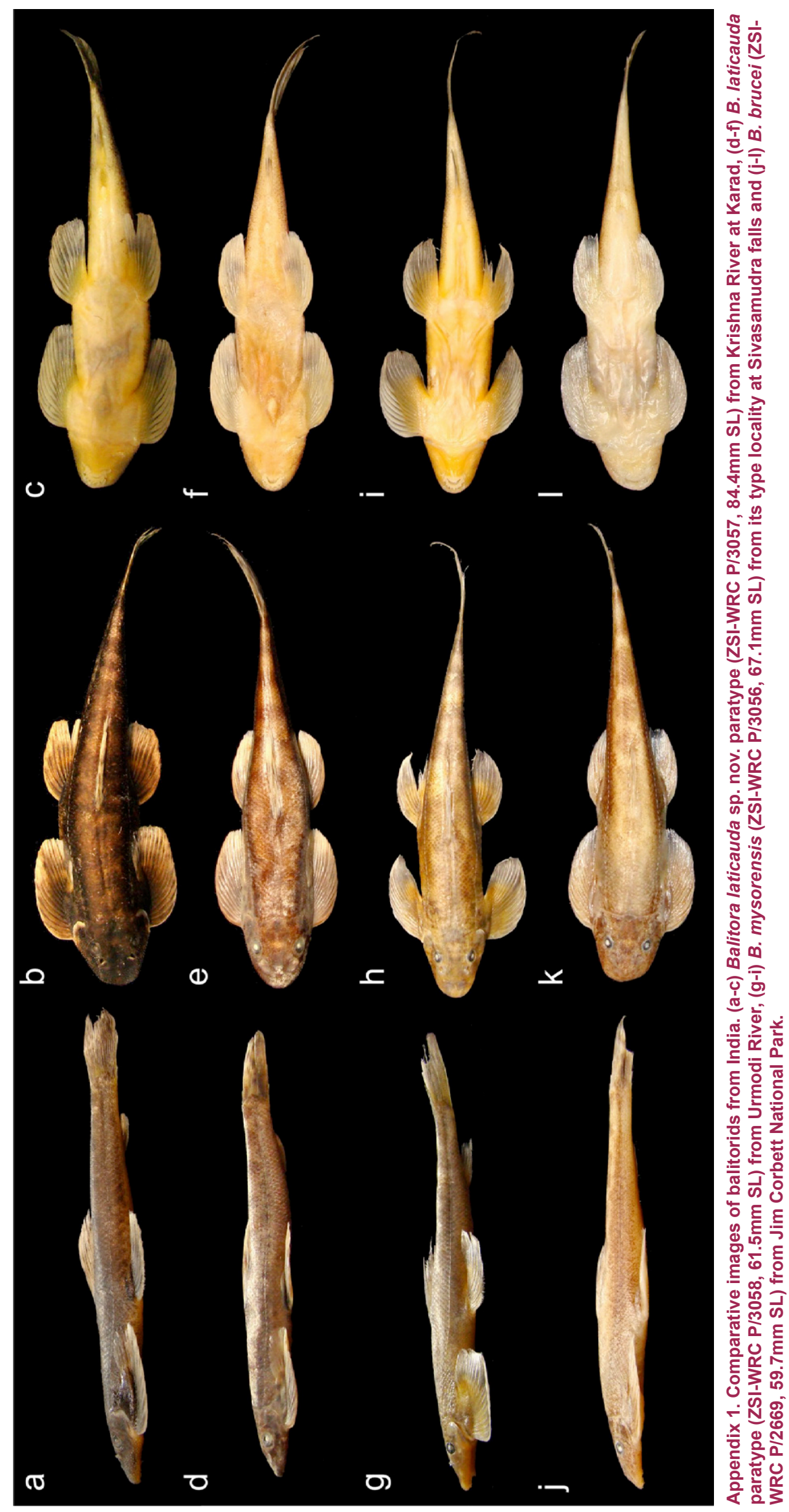

Journal of Threatened Taxa | www.threatenedtaxa.org | September 2012 | 4(11): 3038-3049 
Appendix 2. Biometric data $(\mathrm{mm})$ of Balitora laticauda sp. nov. holotype and eight paratypes.

\begin{tabular}{|c|c|c|c|c|c|c|c|c|c|}
\hline & Holotype & Paratype 1 & Paratype 2 & Paratype 3 & Paratype 4 & Paratype 5 & Paratype 6 & Paratype 7 & Paratype 8 \\
\hline Character & $\mathrm{P} / 2848$ & $\mathrm{P} / 2849$ & $\mathrm{P} / 2850$ & $\begin{array}{l}\text { WILD- } \\
\text { PIS-019 }\end{array}$ & $P / 2851$ & $P / 2851$ & $P / 3058$ & $\mathrm{P} / 3057$ & $\mathrm{P} / 3057$ \\
\hline Standard length & 69.5 & 79.8 & 63.6 & 48.7 & 62.7 & 59.7 & 61.5 & 54.0 & 84.4 \\
\hline Total length & 84.4 & 95.1 & 77.3 & 59.2 & 77.2 & 73.7 & 75.9 & 63.8 & 98.3 \\
\hline Head length & 15.2 & 16.6 & 12.8 & 10.1 & 13.1 & 12.8 & 13.5 & 11.0 & 17.0 \\
\hline Dorsal head length & 15.0 & 15.5 & 12.6 & 9.9 & 13.7 & 13.0 & 12.9 & 12.1 & 15.5 \\
\hline Gape of mouth & 3.3 & 4.5 & 2.8 & 2.4 & 2.9 & 3.0 & 2.3 & 2.8 & 4.3 \\
\hline Predorsal length & 31.5 & 37.9 & 27.8 & 22.9 & 28.8 & 27.6 & 29.0 & 24.9 & 38.2 \\
\hline Dorsal to caudal distance & 38.7 & 42.8 & 36.4 & 26.8 & 35.0 & 33.5 & 33.5 & 30.7 & 47.5 \\
\hline Prepectoral fin length & 11.3 & 10.9 & 9.4 & 7.8 & 9.0 & 9.3 & 9.9 & 8.0 & 11.0 \\
\hline Prepelvic length & 30.8 & 37.9 & 28.8 & 22.7 & 29.4 & 28.3 & 28.6 & 26.1 & 37.8 \\
\hline Preanus length & 47.3 & 55.7 & 43.8 & 33.9 & 43.6 & 42.2 & 43.4 & 37.1 & 61.7 \\
\hline Preanal length & 53.5 & 62.9 & 49.1 & 36.2 & 48.6 & 46.2 & 48.8 & 41.1 & 66.3 \\
\hline Ventral fin to anus distance & 16.9 & 20.6 & 16.4 & 12.7 & 14.2 & 15.0 & 15.1 & 12.9 & 23.2 \\
\hline Anal fin to anus distance & 5.4 & 5.5 & 4.3 & 3.2 & 4.3 & 4.2 & 4.5 & 3.6 & 4.8 \\
\hline Head depth at eye & 5.8 & 6.6 & 4.6 & 3.6 & 5.1 & 4.9 & 4.7 & 4.2 & 6.5 \\
\hline Head depth at nape & 7.0 & 7.2 & 5.4 & 4.2 & 6.2 & 6.1 & 5.5 & 4.9 & 7.8 \\
\hline Body depth (D) & 9.3 & 10.0 & 7.4 & 5.6 & 8.2 & 7.6 & 7.2 & 6.9 & 10.2 \\
\hline Body depth (A) & 7.8 & 8.5 & 6.0 & 4.4 & 6.4 & 6.1 & 6.6 & 6.2 & 7.8 \\
\hline Depth of caudal peduncle & 4.9 & 5.4 & 4.4 & 3.1 & 4.6 & 4.4 & 4.6 & 4.0 & 5.6 \\
\hline Length of caudal peduncle & 12.2 & 12.0 & 12.7 & 8.6 & 11.8 & 10.4 & 10.5 & 10.7 & 13.3 \\
\hline Snout length & 8.8 & 10.2 & 7.5 & 5.4 & 7.6 & 7.2 & 7.1 & 6.1 & 9.1 \\
\hline Head width (at nares) & 10.0 & 12.5 & 8.8 & 6.9 & 9.5 & 8.1 & 8.6 & 7.8 & 12.2 \\
\hline Maximum head width & 12.0 & 14.0 & 11.8 & 8.9 & 11.7 & 9.9 & 10.9 & 10.3 & 15.8 \\
\hline Body width (D) & 12.4 & 15.1 & 10.4 & 8.2 & 12.1 & 10.4 & 10.7 & 10.4 & 16.7 \\
\hline Body width (A) & 8.3 & 9.1 & 5.7 & 4.6 & 6.8 & 5.2 & 5.8 & 5.1 & 7.7 \\
\hline Eye diameter & 2.0 & 2.6 & 1.9 & 1.7 & 1.8 & 2.0 & 2.1 & 2.3 & 1.8 \\
\hline Interorbital width & 6.0 & 5.6 & 5.2 & 3.9 & 5.9 & 5.5 & 5.3 & 4.7 & 6.0 \\
\hline Height of dorsal fin & 12.9 & 14.1 & 12.7 & 9.1 & 12.2 & 11.3 & 11.8 & 11.1 & 13.8 \\
\hline Dorsal fin base & 10.5 & 11.9 & 9.2 & 7.2 & 8.7 & 9.4 & 9.9 & 8.4 & 12.8 \\
\hline Length of upper caudal lobe & 12.5 & 14.7 & 12.6 & 9.5 & 12.8 & 12.5 & 12.4 & damaged & 13.3 \\
\hline Length of lower caudal lobe & 16.7 & 16.5 & 13.3 & 10.4 & 14.8 & 14.0 & 15.0 & damaged & 13.6 \\
\hline Length of median caudal rays & 10.2 & 12.0 & 8.6 & 6.0 & 9.4 & 8.6 & 10.2 & 6.7 & 11.5 \\
\hline Height of anal fin & 8.1 & 11.1 & 7.5 & 5.7 & 8.4 & 8.1 & 8.6 & 6.8 & 9.5 \\
\hline Anal fin base & 4.6 & 5.1 & 3.3 & 3.6 & 3.6 & 3.7 & 3.7 & 3.3 & 5.3 \\
\hline Length of pelvic fin & 15.1 & 17.0 & 13.7 & 9.4 & 13.8 & 12.9 & 13.5 & 12.8 & 17.5 \\
\hline Length of pectoral fin & 16.7 & 22.4 & 16.5 & 12.7 & 16.9 & 14.6 & 15.8 & 15.6 & 21.2 \\
\hline$D$ & iii, 8 & iii, 8 & iii, 8 & iii, 8 & iii, 8 & iii, 8 & iii, 8 & iii, 8 & $\mathrm{iii}, 7$ \\
\hline A & iii, 5 & iii, 5 & iii, 5 & iii, 5 & iii, 5 & iii, 5 & ii, 5 & $\mathrm{ii}, 5$ & ii, 5 \\
\hline$P$ & ix, 10 & viii, 10 & ix, 10 & viii, 11 & viii, 11 & viii, 11 & vii, 11 & vii, 11 & vii, 11 \\
\hline V & ii, 9 & ii, 9 & ii, 8 & ii, 8 & ii, 8 & ii, 8 & ii, 8 & ii, 8 & ii, 8 \\
\hline L.I. scales & 67 & 66 & 68 & 67 & 67 & 66 & 68 & 67 & 68 \\
\hline LL to ventral scales & 8 & 8 & 7 & 9 & 8 & 8 & 6 & 8 & 6 \\
\hline LL to dorsal scales & 8 & 8 & 8 & 9 & 8 & 8 & 9 & 8 & 9 \\
\hline Predorsal scales & 20 & 25 & 19 & 23 & 20 & 19 & 20 & 21 & 21 \\
\hline
\end{tabular}


Appendix 3. Biometric data $(\mathrm{mm})$ of Balitora mysorensis holotype (ZSI Kolkata F13512/1) and two specimens collected from the type locality.

\begin{tabular}{|c|c|c|c|}
\hline Character & Holotype* & $\begin{array}{c}\mathrm{P} / 3056 \\
(\# 1)\end{array}$ & $\begin{array}{l}\mathrm{P} / 3056 \\
(\# 2)\end{array}$ \\
\hline Standard length & 38.8 & 67.1 & 68.3 \\
\hline Total length & - & 84.7 & 83.4 \\
\hline Head length & 8.9 & 13.3 & 13.4 \\
\hline Dorsal head length & - & 12.3 & 13.5 \\
\hline Gape of mouth & - & 2.7 & 2.5 \\
\hline Predorsal length & - & 29.7 & 30.5 \\
\hline Dorsal to caudal distance & - & 38.0 & 38.1 \\
\hline Prepectoral fin length & - & 10.5 & 10.3 \\
\hline Prepelvic length & - & 31.2 & 31.4 \\
\hline Preanus length & - & 47.2 & 48.8 \\
\hline Preanal length & - & 52.7 & 54.0 \\
\hline Ventral fin to anus distance & - & 16.4 & 17.4 \\
\hline Anal fin to anus distance & - & 5.7 & 4.7 \\
\hline Head depth at eye & - & 5.2 & 5.4 \\
\hline Head depth at nape & 4.0 & 5.9 & 6.1 \\
\hline Body depth (D) & 5.1 & 7.4 & 7.5 \\
\hline Body depth $(A)$ & - & 5.7 & 6.1 \\
\hline Depth of caudal peduncle & 2.1 & 3.5 & 3.5 \\
\hline Length of caudal peduncle & 6.2 & 11.6 & 10.4 \\
\hline Snout length & 5.5 & 8.0 & 8.3 \\
\hline Head width (at nares) & - & 8.3 & 8.6 \\
\hline Maximum head width & 6.3 & 10.6 & 10.4 \\
\hline Body width (D) & 6.2 & 11.2 & 11.9 \\
\hline Body width (A) & - & 5.2 & 6.0 \\
\hline Eye diameter & 1.6 & 1.8 & 1.9 \\
\hline Interorbital width & 2.9 & 4.8 & 4.9 \\
\hline Height of dorsal fin & 8.0 & 10.7 & 9.5 \\
\hline Dorsal fin base & - & 11.1 & 8.9 \\
\hline $\begin{array}{l}\text { Length of upper caudal } \\
\text { lobe }\end{array}$ & - & 11.6 & 13.4 \\
\hline $\begin{array}{l}\text { Length of lower caudal } \\
\text { lobe }\end{array}$ & - & 17.8 & 16.9 \\
\hline $\begin{array}{l}\text { Length of median caudal } \\
\text { rays }\end{array}$ & - & 7.6 & 7.5 \\
\hline Height of anal fin & 7.0 & 7.7 & 7.7 \\
\hline Anal fin base & - & 4.1 & 4.4 \\
\hline Length of pelvic fin & 8.9 & 14.2 & 14.1 \\
\hline Length of pectoral fin & 10.2 & 16.0 & 17.2 \\
\hline D & iii, 9 & iii, 8 & iii, 8 \\
\hline A & ii, 5 & ii, 5 & ii, 5 \\
\hline $\mathrm{P}$ & ix, 12 & viii, 10 & viii, 10 \\
\hline $\mathrm{V}$ & ii, 9 & ii, 8 & ii, 8 \\
\hline L.I. scales & - & 68 & 69 \\
\hline LL to ventral scales & - & 6 & 6 \\
\hline LL to dorsal scales & - & 9 & 9 \\
\hline Predorsal scales & - & 21 & 21 \\
\hline
\end{tabular}

* - = data not available
Switzerland and Zoo Outreach Organisation, Coimbatore, India, 116p.

Dahanukar, N., R. Raut \& A. Bhat (2004). Distribution, endemism and threat status of freshwater fishes in the Western Ghats of India. Journal of Biogeography 31(1): 123-136.

Hora, S.L. (1941). Homalopterid fishes from peninsular India. Records of the Indian Museum 43(2): 221-232.

Kalawar, A.G. \& C.N. Kelkar (1956). Fishes of Kolhapur. Journal of the Bombay Natural History Society 53(4): 669-679.

Kottelat, M. (1988). Indian and Indochinese species of Balitora (Osteichthyes: Cypriniformes) with descriptions of two new species and comments on the family-group names Balitoridae and Homalopteridae. Revue Suisse de Zoologie 95(2): 487-504

Li, Z.-Y. \& Y.-R. Chen (1985). On two new species of Homalopteridae fishes from Yunnan. Zoological Research 6(2): 169-173.

Liu, S.-W., Y. Zhu, R.-F. Wei \& X.-Y. Chen (2012). A new species of the genus Balitora (Teleostei: Balitoridae) from Guangxi, China. Environmental Biology of Fishes 93(3): 369-375.

Menon, A.G.K. (1987). The fauna of India and adjacent countries, Pisces, Vol 4, Teleostei-Cobitoidea, Part 1, Homalopteridae. Zoological Survey of India, Kolkata, 259pp.

Nguyen, V.H. (2005). Ca Nuoc Ngot Viet Nam. Tap II. Nha Xuat Ban Nong Nghiep, Viet Nam, 760pp.

Raghavan, R., N. Dahanukar, K. Krishnakumar, A. Ali, S. Solomon, M.R. Ramprasanth, F. Baby, B. Pereira, J. Tharian \& S. Philip (2012). Western Ghats fish fauna in peril: are pseudo conservationist attitudes to be blamed? Current Science 102(6): 835-837.

Zheng, C.-Y.(1980). On a new fish of the family Homalopteridae from Yunnan, China. Journal of Jinan University (Natural Science) 1980(1): 110-112.

Zheng, C.-Y., Y.-R. Chen \& S. Huang(1982). The homalopterid fishes from Yunnan Province, China. Zoological Research 3(4): 393-402.

Acknowledgements: We are grateful to the Director, Zoological Survey of India, Kolkata, for permission to examine the type material available at fish section, ZSI, Kolkata. We are thankful to Dr. R.M. Sharma, Scientist-D \& Officer-in-Charge, ZSI, Western Regional Centre, Pune for providing facilities and encouragement. We are thankful to Rahul Kumar for providing us the specimens of Balitora mysorensis from the type locality and suggesting corrections in the galley proof. We greatfully acknowledge Sadashiv Nayak for the photograph of live Balitora mysorensis. We thank Madhavi Chavan for providing us specimens of the new species from Khodashi Village. We are also thankful to Mandar Paingankar, Rajeev Raghavan and Anvar Ali for helpful discussion. Comments from two anonymous reviewers and the subject editor improved the quality of the paper substantially. The study was self funded. However the CEPFfunded freshwater assessment of the Western Ghats made us realize the taxonomic issues in the freshwater fishes and current description of the new species is a follow up of the same work. We duly acknowledge the help from CEPF for publication of this article. 